\title{
Sensing Properties of Palladium and Lanthanide Porphyrinates Embedded in Nanoporous Silica Gel Materials
}

\author{
Elena G. Ermolina, ${ }^{a}$ Rimma T. Kuznetsova, ${ }^{a}{ }^{a}$ Tat'yana N. Kopylova, $^{a}$ \\ Georgii V. Mayer, ${ }^{a}$ Tat'yana A. Pavich, ${ }^{\text {b }}$ Sergey M. Arabei, ${ }^{c}$ \\ and Konstantin M. Solovyov \\ ${ }^{a}$ Tomsk State University, 634045 Tomsk, Russia \\ bB.I. Stepanov Institute of Physics, National Academy of Sciences of Belarus, 220072 Minsk, Belarus \\ 'Belorussian State Agrarian Technical University, 220023 Minsk, Belarus \\ @Corresponding authorE-mail: kuznetrt@phys.tsu.ru
}

\begin{abstract}
Solid gel-films and volume gel-matrices on the basis of silica materials doped with palladium porphyrinate, lutetium and gadolinium tetraphenylporphyrinates were prepared. Spectral-luminescent, sensing properties to molecular oxygen and effect of the gas environment were studied. Nanoporous silicate gel-materials doped by palladium porphynate demonstrate relatively high sensitivity to oxygen and can be considered as perspective optical sensors for oxygen.
\end{abstract}

Keywords: Palladium porphyrin, lutetium and gadolinium tetraphenylporphyrin, nanoporous gel-materials, quenching of phosphorescence, optical sensors for oxygen.

\section{Сенсорные свойства порфиринатов палладия и лантанидов, внедренных в нанопористые силикатные гель-материалы}

\author{
Е. Г. Ермолина, ${ }^{a}$ P. Т. Кузнецова, ${ }^{a}$ T. Н. Копылова, ${ }_{1}^{a}$ Г. В. Майер, ${ }^{a}$ T. А. Павич, ${ }^{b}$ \\ С. М. Арабей, ${ }^{\mathrm{b}, \mathrm{c}}$ K. Н. Соловьёв ${ }^{\mathrm{b}}$

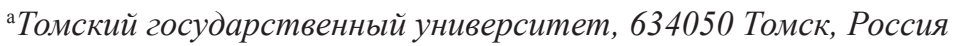 \\ ${ }^{\mathrm{b}}$ Институт физики им. Б.И. Степанова НАН Беларуси, 220072 Минск, Беларусь \\ ${ }^{\mathrm{c}}$ Белорусский государственный аграрный технический университет, 220023 Минск, Беларусь
}

\begin{abstract}
Получень твердотельные гель-плёнки и объёмные гель-матриць на основе силикатных материалов, допированные порфиринатом палладия, тетрафенилпорфиринатами лютеция и гадолиния, которые исследованы на чувствительность к молекулярному кислороду. Изучены спектрально-люминесиентные и сенсорные свойства синтезированных материалов, влияние на них состава окружающей газовой смеси. Нанопористые силикатные гель-материаль, допированные порфиринатом палладия, проявляют относительно высокую чувствительность к кислороду и могут рассматриваться как перспективные оптические сенсоры на кислород.
\end{abstract}

Ключевые слова: Порфиринат палладия, тетрафенилпорфиринат лютеция и гадолиния, нанопористые гельматериалы, тушение фосфоресценции, оптические сенсоры на кислород. 


\section{Introduction}

Porphyrin complexes with some metals possess a huge potential in optical sensing because of their significant values of absorption coefficients, high phosphorescence quantum yields in milli- and microsecond range and photostability. Octaethylporphyrin complexes with platinum and palladium possess an intensive phosphorescence at room temperature (for example $\varphi_{\mathrm{ph}} \approx 0.45$ for PtOEP in liquid solution ${ }^{[1]}$ ) and are especially perspective in optical oxygen sensing. ${ }^{[2-5]}$ The active search for compounds possessing high sensitivity to oxygen is directed towards related metalloporphyrins and other compounds including transition metal complexes ${ }^{[6,7]}$ and polycyclic aromatic hydrocarbons. ${ }^{[8,9]}$ Sensing material to specific analyte is useful as a solid-state matrix colored by sensitive compounds.

In addition to the active molecule, the chemical composition and structure of matrix is crucial to final material sensitivity to oxygen. ${ }^{[10,11]}$ It must be manufacturable, highly porous, transparent in a wide spectral range and must not provoke photochemical degradation of the dye molecule. Materials obtained by the sol-gel technology satisfy all these requirements. Best results have been obtained when dyes were incorporated to organically modified materials..$^{[7-9]}$

Here we have synthesized and studied silica gelmaterials doped by intensive phosphorescensing substances: palladium porphyrinate (PdP) and lutetium and gadolinium tetraphenylporphyrinates (LuClTPP, GdClTPP). These complexes are used for the first time as agents for oxygen optical sensing. LuClTPP and GdClTPP in other environments were studied in our earlier works. ${ }^{[13,17]}$

\section{Experimental}

The structural formulas and abbrivations of the studied metalloporphyrins are presented in Figure 1. Dye solutions in ethanol and dimethylformamide (DMF) were studied.

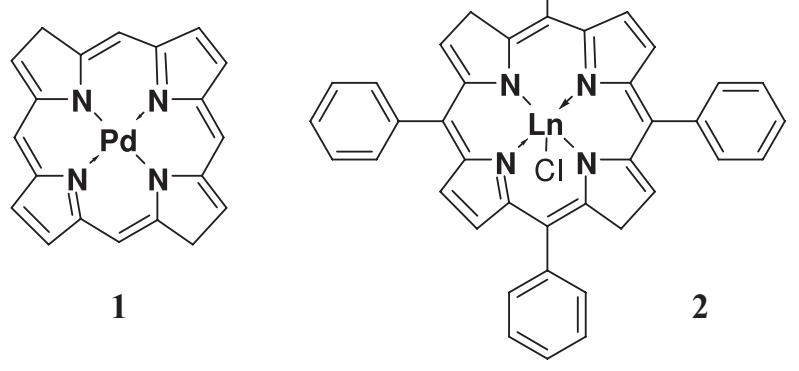

Figure 1. Structures of the studied substances : 1 - palladium porphyrinate (PdP), 2 - lutetium (LuClTPP, $\mathrm{Ln}=\mathrm{Lu}^{3+}$ ) or gadolinium ( $\mathrm{GdClTPP}, \mathrm{Ln}=\mathrm{Gd}^{3+}$ ) tetraphenylporphyrinate.

Luminescence spectra at $298 \mathrm{~K}$ were registered on Cary Eclipse spectrometer (Varian). Luminescence quantum yields were determined by the standard method with an error of $10 \%$ using ZnTPP as a standard. ${ }^{[12]}$ The phosphorescence lifetime was estimated from the exponential $I_{0} / I$ dependences on time $t$ with variable radiation delay time.
Sensing properties of gel-films with incorporated metalloporphyrins were probed on original setup, ${ }^{[13]}$ built around an SM2203 spectrometer (Solar) and consisted of an UFPGS-4 device intended for generating gas mixture flow, a gas cell with the examined sample put in the cell block of the spectrometer, and a personal computer. Pure oxygen (99.99\%, "Pure gases") was used as a gas-analyte, and pure argon (99.99\%, "Pure gases") was used as a gas-diluent. Gas mixture composition was controlled by PC with accuracy to 0.05 vol. \%. Studying solid samples coloured with metalloporphyrins were put in the hermetic gas cell made of stainless steel with the polished internal surface and were oriented at an angle of 30 degrees to the exciting beam, i.e. frontal excitation was used.

Thin silicate gel-films were prepared by the method described in ${ }^{[14]}$. The initial reaction mixture contains tetraethoxysilane (TEOS), ethanol, water and small catalytic amount of hydrochloric acid in molar ratio TEOS: $\mathrm{C}_{2} \mathrm{H}_{5} \mathrm{OH}: \mathrm{H}_{2} \mathrm{O}: \mathrm{HCl}=1: 6: 4: 0.06$. The mixture was stirred with a magnetic stirrer during three hours at room temperature for the full hydrolysis. Saturated metalloporphyrin solution in DMF or ethanol (about 6 vol. \%) was added to the obtained sol-solution, the mixture was thoroughly stirred. To prevent demetallation and protonation of the free base porphyrin, observed in ${ }^{[18]}$, acidity of the sol-mixture was raised to $\mathrm{p} H \sim 6$ by aqueous ammonia addition before dyes addition. Thin silica gelfilms were formed on quartz substrates from prepared colored solmixture by spin-coating. The obtained silica gel-films of micrometer thick were dried at increase of temperature of 1 degree per minute up to $120^{\circ} \mathrm{C}$ and then subsequent slow cooling to room temperature to remove the solvent from nanopores. For the volume bulks preparation obtained sol-mixture was poured into the polystyrene rectangular cuvettes. The obtained matrices were dried for the first five days at $60{ }^{\circ} \mathrm{C}$, then 1 month at $40{ }^{\circ} \mathrm{C}$ in the closed cuvette and one month in an open cuvette on the air without heating.

To reduce the concentration of hydroxyl groups on the gel material porous surface the sols with two ratios of volume fractions TEOS and vinyltriethoxysilane (VTEOS) - 70:30 and 50:50 - have been prepared. Thin silica gel-films on the TEOS:VTEOS basis were also formed by spin-coating on quartz substrates.

\section{Results and Discussion}

\section{Palladium Porphyrinate}

Absorption spectra of gel-films doped by PdP can not be registered due to the low optical density of samples (at the noise level). But luminescence spectra of PdP in gel-film under Soret-band excitation are easily registered. Absorption spectrum of PdP in TEOS:VTEOS bulk contains bands at 386 (Soret), $502\left(Q_{01}\right)$ and $534\left(Q_{00}\right) \mathrm{nm}$ and is close to PdP absorption in DMF ${ }^{[9,13,15]}$ Fluorescence spectra of the obtained solid-state films and bulks coincide with the fluorescence spectra of PdP in DMF solution (Figure 2). Phosphorescence spectrum of PdP in gel-film and volume matrix $\left(\lambda_{\mathrm{ex}}=370 \mathrm{~nm}\right)$ under argon is presented by 0-0-band with maximum at 647 $\mathrm{nm}$ and vibrational satellite at $716 \mathrm{~nm}$ (Figure 3), that is close to phosphorescence spectrum of PdOEP. ${ }^{[1]}$ Phosphorescence excitation spectrum of PdP registered at 647 and $716 \mathrm{~nm}$ in these patterns coincides with absorption (Figure 2, curves 1 and 4). Lifetime measuring at 647 and $716 \mathrm{~nm}$ gives the same result -460 microseconds (mcs), the decay kinetics followed a monoexponential equation, that proves the presence of only one PdP spectral form (neutral and monomeric) in silica gelfilm on the basis of TEOS:VTEOS.

When solid-state sample doped by PdP was placed in the cuvette cell of the setup for sensing properties studing, 


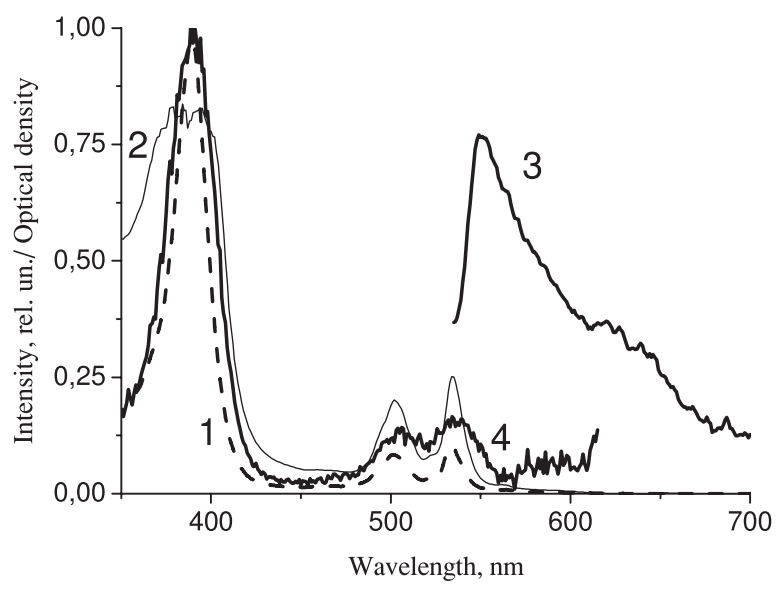

Figure 2. Absorption spectrum of PdP in DMF - 1; absorption spectrum - 2; fluorescence spectrum $\left(\lambda_{\text {ex }}=370 \mathrm{~nm}\right)-3$ of PdP in the TEOS:VTEOS bulk $(1: 1)$, and phosphorescence excitation spectrum $\left(\lambda_{\text {reg }}=650 \mathrm{~nm}\right)-4$ of PdP in the TEOS:VTEOS gel-film $(1: 1)$.

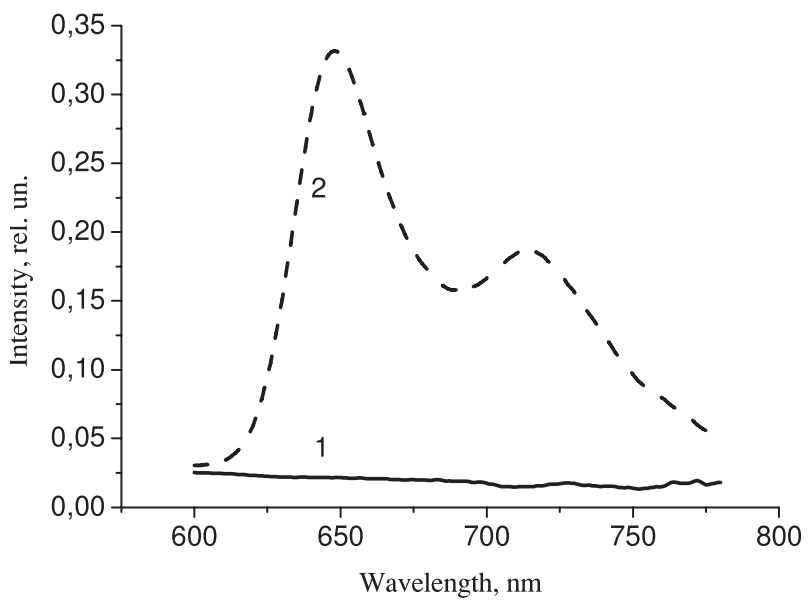

Figure 3. Phosphorescence spectra of PdP in TEOS:VTEOS (1:1) gel-film in pure oxygen (1) and in pure argon (2). $\lambda_{\mathrm{ex}}=370 \mathrm{~nm}$.

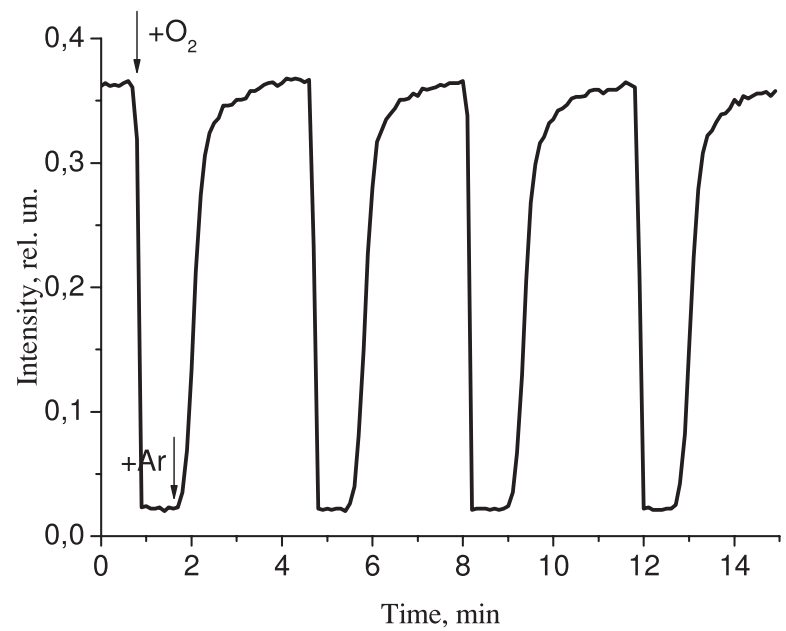

Figure 4. Response time and phosphorescence intensity change for PdP in TEOS:VTEOS (1:1) gel-film on switching between $100 \%$ argon and $100 \%$ oxygen $\left(\lambda_{\text {reg }}=647 \mathrm{~nm}\right)$. phosphorescence intensity increases under argon and drops to zero under oxygen (Figure 3). Relative intensity change on switching between $100 \%$ argon and $100 \%$ oxygen is presented in Figure 4.

Important characteristics of optical sensor are the system response time to incoming analyte (oxygen in our case), range of measurable concentrations, and primarily the sensitivity to analyte determined by the ratio $I_{0} / I_{100}$ for optical sensors, where $I_{0}$ and $I_{100}$ are the luminescence intensities for analyte concentrations of 0 and $100 \%$, respectively. ${ }^{[3]}$

One can see from Figure 4 that the response time of the obtained material on the basis of PdP to analyte flow is small enough - about $1 \mathrm{sec}$. Response time to the removal of analyte is much longer - about 2 minutes. It can be explained by more effective formation of PdP in triplet state complexes with oxygen, than their dissociation under argon flow. The sensitivities to oxygen for the obtained gel-materials doped by PdP are given in Table 1 . The obtained values $I_{0} / I_{100}$ are high enough to quantity determination of small concentrations (up to $3 \%$ ) of oxygen.

Table 1. Sensitivity $\left(I_{0} / I_{100}\right)$ of gel-materials doped by PdP to oxygen

\begin{tabular}{ccc}
\hline Gel-material & $\begin{array}{c}\text { Component ratio } \\
\text { TEOS:VTEOS, } \\
\text { vol. \% }\end{array}$ & $I_{0} / I_{100}$ \\
\hline \multirow{2}{*}{ Film } & $50: 50$ & 16.0 \\
Bulk & $100: 0$ & 2.0 \\
\hline
\end{tabular}

The analysis of the Table 1 data shows that organically modified TEOS:VTEOS bulks have increased sensitivity in comparison with bulks from TEOS only. Thus, $I_{0} / I_{100}$ is increased from 2.0 for gel-film from pure TEOS to 16.0 for TEOS:VTEOS gel-film with $50 \%$ VTEOS.

For the materials studied the Stern-Volmer plots $I_{0} / I=1+K^{\mathrm{Sv}}\left[\mathrm{O}_{2}\right]$ were obtained, where $I_{0}$ and $I$ are the luminescence intensities without oxygen and with oxygen concentration $\left[\mathrm{O}_{2}\right]$, respectively; and $K^{\mathrm{SV}}$ is the SternVolmer quenching constant. Stern-Volmer plot for PdP in TEOS:VTEOS gel-film with $50 \%$ VTEOS (Figure 5) deviates from linear dependence in the direction of the $\mathrm{x}$-axis, that can be due to the presence of two types of luminophor molecules. The first one is located on the surface and accessible for quencher, the other one is located deep in the pores of polymer film. Consistent with our data, the authors ${ }^{[16]}$ have shown that the yield of singlet oxygen arising from the interaction of molecular oxygen with triplet-excited molecules of phthalocyanine differs on the pore surface and within the pores and decreases with decreasing of the pore size in the granules of silica gel.

Such a kind of luminophor shielding decreases the quenching effect with oxygen concentration growth and leads to the quenching saturation. Evaluation of the SternVolmer constants in different linear sections confirms this: $K^{\mathrm{SV}}=1.2 \times 10^{4} \mathrm{M}^{-1}$ under oxygen concentration $<10^{-3} \mathrm{M}$; another value $K^{\mathrm{sv}}=5 \times 10^{2} \mathrm{M}^{-1}$ was obtained in concentration range from $2.5 \times 10^{-3}$ to $8 \times 10^{-3} \mathrm{M}$ (keep in mind that for this interval there is another value of $I_{0}$ ). These data show that determination of small oxygen concentrations with this 
optical sensor is more susceptible and accurate. The further investigations would be produced with measurements of kinetics characteristics of luminescence for the corrective $K_{\text {SV }}$ determinations on the nonlinear parts of the dependence. These studies did not schedule for this paper, because the polymer matrices creation with higher oxygen permeability is more important for the practical use on this stage.

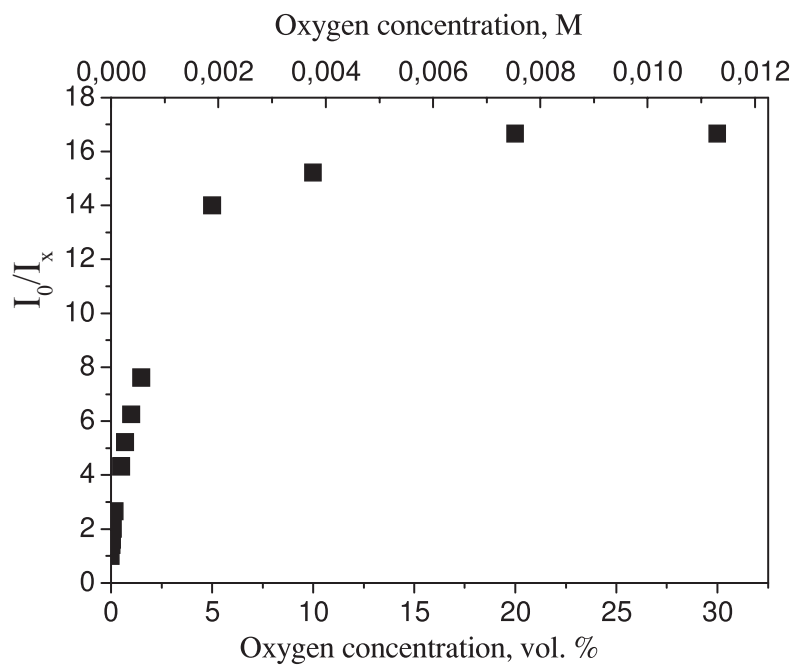

Figure 5. Stern-Volmer plot for PdP in TEOS:VTEOS (50:50) gel-film.

Sensor materials on the basis of platinum and palladium complexes with porphyrins received by several authors $^{[4,8]}$ demonstrate linearity of Stern-Volmer plots in the initial section also - to $12-20 \%$ of oxygen. However, some studies ${ }^{[6,7,10]}$ demonstrate materials with linear to 100 $\%$ oxygen Stern-Volmer plots. In these works the authors used organically modified silica materials, that point out the importance of modifying the environment in high sensitive sensing material creation.

For the high oxygen concentration (more than $20 \%$ ) determination it is needed to search for suitable polymeric materials, that can shift the effect to higher oxygen concentrations. We suggest that one of the ways for such material creation is increasing of sensing molecule ( $\mathrm{PdP}$ in our case) concentration in the matrix.

\section{Lutetium and Gadolinium Porphyrinates}

The study of spectral characteristics of the synthesized solid-state gel-materials doped by lanthanide porphyrins shows demetallization of lanthanide porphyrins with free base porphyrin formation using standard synthetic method. [14] Thus, fluorescence spectra of TEOS-gel-materials doped by LuTPP correspond mainly to fluorescence of the free base $\mathrm{H}_{2}$ TPP $\left(\lambda_{\max }{ }^{\mathrm{fl}}=650\right.$ and $\left.714 \mathrm{~nm}\right)$ (Figure 6), not LuClTPP $\left(\lambda_{\max }^{\mathrm{fl}}=600\right.$ and $\left.650 \mathrm{~nm}\right)$. Most likely, these spectral changes are due to the influence of $\mathrm{OH}$-groups, located on the surface of the pores of silica matrix. This is confirmed by experiments on the spectrophotometric titration (Figure 7) of LuClTPP ethanol solution by $\mathrm{HCl}$.

Results of the spectroscopic titration show that at $\mathrm{pH}$ $=1.450 \%$ of the molecules are in the initial state of complex (LuClTPP), and $50 \%$ - in demetallated state $\left(\mathrm{H}_{2} \mathrm{TPP}\right)$.

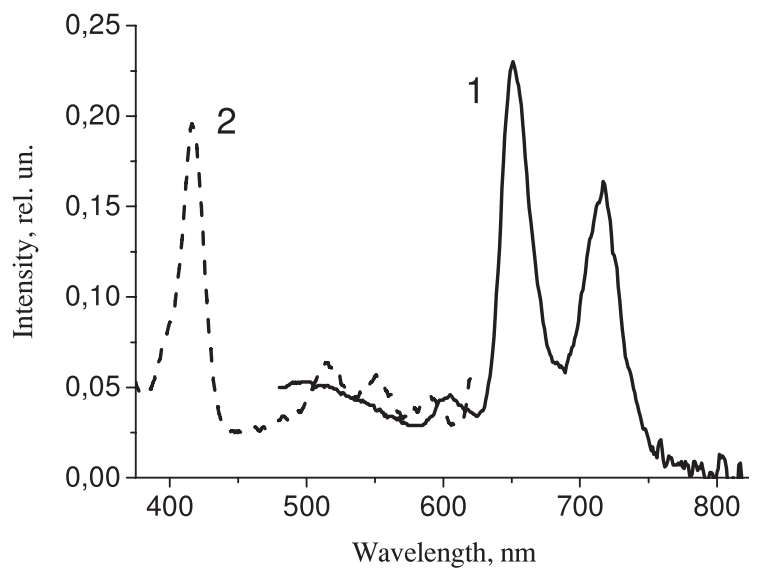

Figure 6. Fluorescence spectra -1 under $\lambda_{\text {ex }}=420 \mathrm{~nm}$ and fluorescence excitation -2 at $\lambda_{\text {reg }}=650 \mathrm{~nm}$ LuClTPP in TEOS gelmatrix.

Despite the fact that the $\mathrm{pH}$ of the sol-gel mixture during the synthesis was increased up to 6 and the lanthanide porphyrin at these conditions are chemically stable (similar to the results of the titration in Figure 7), under nanoporous gelmaterial formation they still have to face demetallization. This confirms the role of the surface hydroxyl groups the concentration of which is increased significantly in the formation and drying of a solid gel-material during the degradation of lanthanide porphyrin. Thus, modification of silica gel-materials is needed to prevent this process.

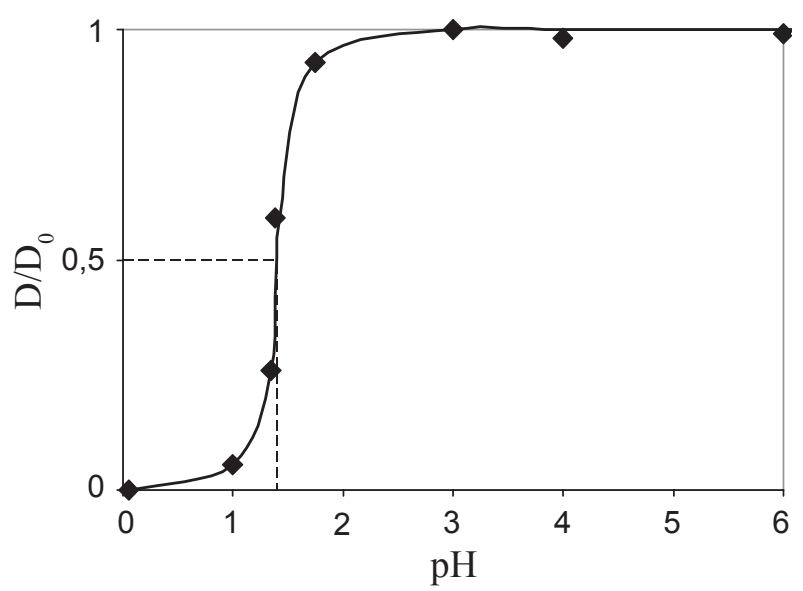

Figure 7. Spectrophotometric titration curve for LuClTPP in ethanol by $\mathrm{HCl}$ solution. $D$ - optical density of the investigated solution at different $\mathrm{p} H ; D_{0}-$ optical density at $\mathrm{p} H=6$.

Modification of silica gel material by introduction of VTEOS to the reaction mixture can significantly reduce the concentration of the surface $\mathrm{OH}$-groups in the pores of the gel-matrix and thus reduce the amount of demetallated molecules of dye relatively metallocomplexes. In this work we have prepared the sols with the ratio of volume fractions TEOS and VTEOS 70:30 and 50:50 and preliminary sol neutralization by aqueous ammonia was made.

Porous materials with greater oxygen permeability (silica gel-matrices, cellulose) compared to previously studied polymer materials ${ }^{[17]}$ (see Table 2) should have a 
higher sensitivity to oxygen. However, the obtained gel-films and gel-matrices doped with lanthanide porphyrins showed low values $I_{0} / I_{100}$ and $K^{\mathrm{sv}}$, what is probably due to a partial demetallation and low intensity of phosphorescence of such films.

Table 2. Sensitivity to oxygen $\left(I_{0} / I_{100}\right)$ for lanthanide porphyrins in organic polymers ${ }^{[17]}$ and silica gel-materials. $\mathrm{MC}-$ methylcellulose, TBM - tert-butyl methacrylate, DAC - diacetylcellulose, S - spincoating, $\mathrm{P}$ - poured.

\begin{tabular}{|c|c|c|c|c|c|}
\hline Substance & Matrix & & $I_{0} / I_{100}$ & $K_{1}^{\mathrm{SV}}$ & $K_{2}^{\mathrm{SV}}$ \\
\hline \multirow{8}{*}{ LuCITPP } & \multirow{2}{*}{$\mathrm{MC}$} & $\mathrm{S}$ & 6.7 & & \\
\hline & & $\mathrm{P}$ & 40.0 & 2930 & 37 \\
\hline & TBM & & 4.9 & & \\
\hline & Styrene & & 5.5 & & \\
\hline & DAC & & 17.5 & 2850 & 16 \\
\hline & \multirow{3}{*}{$\begin{array}{l}\text { TEOS:VTEOS } \\
\text { gel-film }\end{array}$} & 100:0 & 1.9 & & \\
\hline & & $70: 30$ & 2.3 & & \\
\hline & & $50: 50$ & 3.0 & & \\
\hline \multirow{8}{*}{ GdClTPP } & \multirow{2}{*}{$\mathrm{MC}$} & S & 3.3 & & \\
\hline & & $\mathrm{P}$ & 5.1 & 84 & 19 \\
\hline & TBM & & 4.2 & 91 & 3 \\
\hline & Styrene & & 2.9 & & \\
\hline & DAC & & 4.6 & & \\
\hline & \multirow{3}{*}{$\begin{array}{l}\text { TEOS:VTEOS } \\
\text { gel-film }\end{array}$} & $100: 0$ & 1.2 & & \\
\hline & & $70: 30$ & 2.4 & & \\
\hline & & $50: 50$ & 3.5 & & \\
\hline
\end{tabular}

One can see from the Tables 1 and 2 that the sensitivity to oxygen of LuClTPP in methylcellulose film $\left(I_{0} / I_{100}=40\right)$ is higher than for PdP in organically modified silica matrix $\left(I_{0} / I_{100}=12.5\right)$ or in organically modified silica film $\left(I_{0} / I_{100}=\right.$ 16.0). The best result for LuCITPP in poured methylcellulose film can be explained by the higher quantum yield of the phosphorescence (40\%) and, probably, the best ratio of the luminophor concentration, permeability and thickness of the films in this case.

\section{Conclusion}

Palladium porphyrinate incorporated in silica gelmaterials has shown a relatively high sensitivity to oxygen, what indicates the perspectives of its use as a sensor agent to determine oxygen by spectral method. Further it is planned to synthesize variously modified gel-materials doped with lanthanide porphyrins and PdP for complete elimination of chemical degradation of metallocomplexes, as well as to vary the concentration of the luminophor, the structure and porosity of polymer silica materials.

Acknowledgements. This work was supported by RFBR (1202-90008-Bel_a), BRFBR (F12R-049), grant of President RF SS 512.2012.2 and Presidential Scholarship 6667.2013.4.

\section{References}

1. Kwong R.C., Sibley S., Dubovoy T., Baldo M., Forrest S.R., Thompson M.E. Chem. Mater. 1999, 11, 3709-3713.

2. Amao Y., Miyashita T., Okura I. Anal. Chim. Acta 2000, 421, 167-174.

3. Basu B.J. Sens. Actuators B 2007, 123, 568-577.

4. Wu W., Ji S., Guo H., Wang X., Zhao J. Dyes Pigm. 2011, 89, 199-211.

5. Tripathi V.S., Lakshminarayana G., Nogami M. Sens. Actuators B 2010, 147, 741-747.

6. Amao Y. Microchim. Acta 2003, 143, 1-12.

7. McGee K.A., Veltkamp D.J., Marquardt B.J., Mann K.R. J. Am. Chem. Soc. 2007, 129, 15092-15093.

8. Gillanders R.N., Tedford M.C., Crilly P.J., Bailey R.T. J. Photochem. Photobiol. A 2004, 162, 531-535.

9. Basu B.J., Thirumurugan A., Dinesh A.R., Anandan C., Rajam K.S. Sens. Actuators B 2005, 104, 15-22.

10. Tian Y., Shumway B.R., Gao W., Youngbull C., Holl M.R., Johnson R.H., Meldrum D.R. Sens. Actuators B 2010, 150, 579-587.

11. Wang X., Chen H., Zhao Y., Chen X., Wang X. Trends Anal. Chem. 2010, 29, 319-338.

12. Ermolina E.G., Kuznetsova R.T., Gadirov R.M., Maier G.V., Semenishin N.N., Rusakova N.V., Korovin Yu.V. High Energy Chem. 2010, 44, 387-392.

13. Ermolina E.G., Kuznetsova R.T., Solodova T.A., Tel'minov E.N., Kopylova T.N., Mayer G.V., Semenishyn N.N., Rusakova N.V., Korovin Y.V. Dyes Pigm. 2013, 97, 209-2014.

14. Kuznetsova R.T., Mayer G.V., Manekina Yu.A., Tel'minov E.N., Arabei S.M., Pavich T.A., Solovyov K.N. Quant. Electronics 2007, 37, 760-764.

15. Starukhin A., Kruk M., Czerwieniec R. J. Lumin. 2008, 128 , 531-536

16. Kuznetsova N.A., Yuzhakova O.A., Strakhovskaya M.G., Shumarina A.O., Kozlov A.S., Krasnovsky A.A., Kaliya O.L. J. Porphyrins Phthalocyanines 2011, 15, 718-726.

17. Ermolina E.G., Kuznetsova R.T., Ageeva T.A., Semenishyn N.N. Izv. Vyssh. Uchebn. Zaved., Fizika 2012, 55(8/3), 100-101.

18. Arabey S.M., Solovyov K.N., Pavich T.A. J. Appl. Spectrosc. 2002, 69, 695-701. 